\title{
DETERMINANTS OF THE QUALITY OF LIFE IN THE COMMUNES OF THE POZNAŃ AGGLOMERATION: A QUANTITATIVE APPROACH
}

\author{
AndRzej Mizgajski ${ }^{1}$, Marzena WalaszeK², Tomasz KaczmareK ${ }^{2}$ \\ ${ }^{1}$ Institute of Physical Geography and Environmental Planning, Adam Mickiewicz University in Poznań, Poland \\ ${ }^{2}$ Institute of Socio-Economic Geography and Spatial Management, Adam Mickiewicz University in Poznań, \\ Poland.
}

Manuscript received: September 13, 2013

Revised version: May 22, 2014

\begin{abstract}
Mizgajski A., Walaszek M., Kaczmarek T., 2013. Determinants of the quality of life in the communes of the Poznan Agglomeration: A quantitative approach. Quaestiones Geographicae 33(4), Bogucki Wydawnictwo Naukowe, Poznań, pp. 67-80, 1 map, 4 tables, 6 figs. DOI 10.2478/quageo-2014-0050, ISSN 0137-477X.
\end{abstract}

ABSTRACT: Since the 1990s, large urban agglomerations in the countries of Central and Eastern Europe have shown highly dynamic functional and spatial changes resulting from the transformation of their political systems. The aim of this study is to present differences in social, economic and environmental living conditions among the communes of a single agglomeration. This, in turn, allows a discussion, in the first place, of local factors, assuming that national and regional conditions in a given area are uniform. The study focused on the agglomeration of Poznań, which consists of the city of Poznań and 17 surrounding communes (Polish: gmina) forming the district, or 'poviat' (Polish: powiat) of Poznań. The analysis of variations in living conditions uses a set of nine indicators reflecting the local level of development in social, economic and environmental terms. The results lead to the conclusion that the development of urbanisation processes in suburban areas over the past 20 years has had a significant share in improving the living conditions of their inhabitants. In some communes they are, in fact, better than in the central city of Poznan.

KeY words: quality of life, Poznań agglomeration, sustainable development

Andrzej Mizgajski, Institute of Physical Geography and Environmental Planning, Adam Mickiewicz University in Poznań, Dzięgielowa 27, 61-680 Poznań, Poland; e-mail:mizgaj@amu.edu.pl

\section{Introduction}

For most Europeans, urbanised areas are the natural habitat. For this reason, studies of the quality of life in urban agglomerations form an important field of research with an interdisciplinary dimension. If we assume that the essential components that define living conditions have a social, an economic and an environmental dimension, then they show a close relationship with the idea of sustainable development. A study of the quality of life is, however, more operational and less ideological in nature as it focuses on present circumstances rather than on a very long-term perspective, which is generally uncertain. This does not require a direct reference to the global context either, which is heavily emphasised in research on sustainable development.

A synthetic approach to living conditions, or to the quality and standard of living, is not easy because of the many aspects of this issue. It involves meeting various needs of an individual dimension (e.g. income) and a collective one (e.g. public transport). Quality-of-life surveys are one way to monitor socio-economic development, and to verify the performance and efficiency of 
the work of local authorities. They also allow assessing whether the aims and objectives pursued by public authorities translate into results in the form of improved living conditions of the inhabitants.

Since the 1990s, large urban agglomerations in the countries of Central and Eastern Europe have shown very high dynamics of functional and spatial changes resulting from the transformation of their political systems. These processes take different forms in individual agglomerations and are differentiated within them (e.g. Hamilton et al. 2005, Tasan 1999).

The aim of this study is to present differences in social, economic and environmental living conditions between the communes of a single agglomeration. This, in turn, allows discussion, in the first place, of local factors, assuming that national and regional conditions in a given area are uniform.

The present study focused on the agglomeration of Poznań, defined as a group of communes, which consists of the city of Poznan and a group of surrounding communes forming the district ('poviat') of Poznań (Powiat poznański. Jakość przestrzeni i jakość życia, 2008; Poznań poviat. Quality of space and quality of life). Such a research area has a very good base of comparable data obtained in connection with recently completed application projects. They have resulted in the development of the Poznan Agglomeration Development Strategy - Poznań Metropolis 2020 (2011) and the Spatial Planning Study of the Poznań Agglomeration (2012). This allowed a deeper insight into the determinants of differences among the agglomeration's communes.

The overall objective of the study was to show different conditions that affect the quality of life in the communes of the Poznan agglomeration. Methodologically, the aim was to extract a set of indicators reflecting the local social, economic, and environmental aspects of the quality of life. The study had also an applicative objective, which involved providing local authorities and communities with information on their position against neighbours, which should be an incentive for action to eliminate any shortcomings that they might take on their own.

\section{Study area}

The Poznan agglomeration belongs to the group of the fastest growing and most urbanised areas in Poland, which includes four agglomerations: Warsaw, Cracow, Łódź, and Wrocław, and two conurbations: Upper Silesia and the Tri-City of Gdańsk-Gdynia-Sopot. With close to one million inhabitants, it is one of the main elements of the modern settlement system not only in Poland, but also in Europe. In the classification of the European Spatial Planning Observation Network (ESPON), it is one of the 76 regions of a metropolitan nature on the continent. In the Globalisation and World Cities (GAWC) ranking of the world's metropolises, Poznań ranks 252nd out of 526 world metropolises, next to such cities as Bilbao, Hannover or Bordeaux. The competitiveness of the Poznan metropolis at the European scale is determined by such parameters as its social capital and high per capita GDP, as well as modern industrial and academic functions. Poznań has an expanding network of connections with other cities in Poland and Europe, especially in the area of transport, economy, politics, science, and culture. Measures of Poznań's metropolitan nature include its flight connections, financial flows between companies, relations with universities abroad, and international commercial and institutional ties.

The Poznan agglomeration includes the city of Poznan and its suburban area consisting of 17 towns and communes of Poznań poviat. Within the above boundaries, the Poznan agglomeration has a population of 895.5 thousand (2012), with average population density of 412 people per sq. $\mathrm{km}$. The agglomeration's inhabitants account for $2.5 \%$ of the country's population and $26 \%$ of the population of Wielkopolska voivodeship (province). With a population of 553,000, Poznan is the fifth largest city in Poland. It has a negative migration balance because of an outflow of inhabitants to the neighbouring communes. The intensity of suburbanisation is the highest among all Polish cities. After the period of the political and economic transformation of the 1990s, the city of Poznan and the surrounding communes entered a path of dynamic spatial and socio-economic development, accompanied by modernisation of infrastructure, expansion of the labour market, 
and continuous improvement in the quality of life.

The Poznań metropolis stands out in Poland due to several important characteristics:

- a concentration of suburban towns and communes within the administrative boundaries of one large district - a land poviat (Polish: powiat ziemski); other large Polish cities border several poviats directly;

- exceptionally high intensity of the suburbanisation process (emigration of residents to the neighbouring communes of Poznań poviat and the location of economic entities outside Poznań);

- dynamic spatial development which results in significant environmental and infrastructural changes, intensification of traffic, and increased mobility of the population within the urbanising area;

- a high level of economic development as indicated by the value of industrial production, level of entrepreneurship, numerous foreign capital investments, and low unemployment rate, both in Poznań and its neighbouring communes;

- very well developed academic functions, the highest percentage of students in the city's population among large Polish cities, and a high level of internationalisation of research and education;

- innovative ideas for city management, transport organisation, provision of public services, and implementation of tasks related to municipal service management; and

- high living standards manifesting themselves in a well-developed labour market, low unemployment rate, high level of prosperity, good access to services, and residents' satisfaction with the quality of life.

Since 2011, the local governments of the city of Poznań, Poznań poviat and the surrounding communes have pursued a common development strategy known as the Poznan Metropolis 2020. It implements the objectives of the EU Europe 2020 Strategy, i.e. enhancing competitiveness and living standards for the Europeans. The new EU strategic priorities pose specific challenges to the Poznan agglomeration, such as a territorial and functional balance, with particular emphasis on spatial order. Equally important is development that promotes social inclusion, which means that the economy should show a high level of employment and ensure economic, social and territorial cohesion. In the Poznan agglomeration, the EU priorities are closer to citizens owing to the establishment of a regular dialogue between the various actors and levels of government, strengthening their commitment necessary for a successful implementation of the metropolitan strategy.

\section{Research methods}

Quality-of-life studies are an interdisciplinary field of knowledge. They are conducted by sociologists, psychologists, social geographers and economists who assess living conditions on the basis of available information and data, both objective and subjective. In the literature, two approaches to studies of the quality of life are found (see Walaszek 2012).

The first group of methods applies to inhabitants' perception of the various aspects of their lives. Such subjective quality-of-life factors include opinions, attitudes and feelings of the inhabitants concerning life satisfaction, working conditions, financial situation, family, well-being and health, access to services, etc. In this approach, the quality of life is usually the sum of subjective judgments of the inhabitants. Eurostat has presented a proposal for research on the quality of life in European cities. It has issued a report entitled "Perception survey on quality of life in European cities" making use of results obtained over the telephone from inhabitants of 75 European cities.

In Poland, research on the quality of life in cities is not very well developed, and there are very few professional comparative studies of this issue. One reliable study is the publication edited by Czapiński and Panek entitled Diagnoza społeczna 2011 - warunki i jakość życia Polaków (Social diagnosis 2011: Living conditions and the quality of life of Poles). One of the studies included there concerned the inhabitants' sense of satisfaction with living in a particular city. In local studies of the quality of life, Poznan stands out as a city which consistently monitors the quality of life of its inhabitants. To date, eight editions of 
the research have been carried out (in the years 2002-2013). The results are used in city management, allow comparisons of development trends, and form part of the main strategic development documents of the city of Poznan. The studies are conducted by the Centre for Quality of Life, established by the city of Poznan and its Adam Mickiewicz University.

The other group of studies of living conditions seeks to find statistical indicators which allow the most objective presentation of the economic situation of households, environmental and housing conditions, access to cultural, educational, and health-care services, etc. A special area of research is the cost of living, including the cost of housing and transport, and the prices of goods and services. It should be noted that factors affecting the quality of life of individuals are partly interdependent (e.g. income level and education), but there are also those on which people have no direct impact. In the latter case, a decisive role is played by state policy and the activity of the local government, for example in such areas as health care, basic education, and public transport. The condition of the environment is also a factor independent of individuals but which could significantly affect their well-being.

The Mercer Quality-of-Living Survey ranking is popular in terms of comparing the quality of life in cities. It covers 221 cities around the world and is based on 39 criteria. The main indicators focus on security, education, hygiene, health, social care, culture, environment, recreation, public transport, and the political and economic situation. In addition to the main list concerning the overall quality of life in cities, Mercer also prepares rankings of the greenest and safest urban centres in the world. It also develops a ranking of costs and quality of life. Mercer's Cost-of-Living Survey Report compares the prices of products and services in the largest cities of the world. In Poland, rankings of the quality of life in cities are published by prominent periodicals such as Newsweek and Przekrój. The latter also publishes a ranking of the best cities to live in.

The present study sought indicators that significantly differentiated at a local scale as a result of both, determinants beyond the control of a commune and those that reflect the activity of commune authorities and communities in vari- ous fields. Examples of external factors include location in relation to the metropolis and main roads, as well as natural beauty. Controllable factors, in turn, include the level of social capital and the size of investment in infrastructure.

Before selecting indicators, the authors made certain presuppositions. It was decided that the analysis would focus on three indicators illustrating local social, economic and environmental determinants. This limit on the number of indicators was due to the procedure of calculation of a synthetic indicator of the quality of life in the communes: it was calculated as an average of standardised indicators for each characteristic. The greater the number of indicators, the stronger the likelihood of their being correlated, which would distort the result. An equal number for each of the determinants ensured that the synthetic indicator did not favour any of the groups determining the quality of life.

The primary criterion of the selection of characteristics for analysis was covering a variety of aspects with minimum relationships between indicators within the same group. Parameters which differed little between the agglomeration's communes were left out. In general, indicators possible to construct on the basis of statistical reports were selected, which ensured the comparability of data not only within the analysed agglomeration, but would also facilitate subsequent comparative studies with other agglomerations. An exception to this rule was the indicator showing the availability of public transport, which was based on unique studies conducted for the Poznań agglomeration.

To illustrate social aspects, the following indicators were selected:

- voter turnout in the first round of the last local elections in 2010,

- share of persons in households receiving social assistance in the total population,

- average number of criminal offences in the years 2010-2012 per 10,000 inhabitants.

These indicators show the level of social inequality in the communes, the state of public safety, and the degree of the community's involvement in the management of the commune's affairs.

The economic sphere was characterised through: 
- commune's total income per inhabitant,

- commune's expenditure on investment per inhabitant (average value for the years 20092011), and

- personal income tax per inhabitant.

These parameters reflect the size of funds at the disposal of local authorities, the amount of resources allocated to investments that can serve the community, and the wealth of the commune's inhabitants.

To describe the environmental component of living conditions, the following were taken into account:

- share of inhabitants with access to the sewerage system,

- share of buildings at a distance greater than 500 metres from a public transport stop,

- share of woodland in the commune's area.

This group of indicators shows the availability of recreational areas, the level of pressure on water quality, and the availability of public transport. Air-quality indicators for communes were not included in this group since one should not expect major differences at this scale, and, from the inhabitants' perspective, the vicinity of nuisance facilities and traffic routes is more important. The reason for not including a waste management indicator is the ongoing process of unification of this field of public utilities management across the country.

The value of each indicator was first relativised to the size of the population, then standardised, and mean values for each of the three groups of indicators and all nine indicators collectively were calculated. This allowed a comparative analysis of the communes in social, economic, and environmental aspects, and a classification of the agglomeration's communes by a synthetic indicator of the quality of life.

The main source of data on the basis of which most of the economic, social and environmental indicators were prepared (six of the nine presented in the article) was the Local Data Bank of the Polish Central Statistical Office (GUS). The social indicator concerning the average number of criminal offences in the years 2010-2012 per 10,000 inhabitants was developed on the basis of absolute data provided by the Police Headquarters in Poznań. Information on the percentage of buildings at a distance of not more than 500 me- tres from the nearest public transport stop was derived from the Study of the Spatial Planning of the Poznań Agglomeration (Gadziński 2012), while data on voter turnout in the 2010 local elections were obtained from the reports of the National Electoral Commission published on the official website http:/ / pkw.gov.pl/.

Given the availability of data in the Local Data Bank of the Polish Central Statistical Office at the time of preparation of this publication, most of the indicators refer to the state of affairs in 2011. In the case of a commune's expenditure on investment per inhabitant, a mean for three years (2009-2011) was calculated, and in the case of the average number of offences, a mean for the years 2010-2012. The voter turnout rate applies to the first round of the last local elections held in 2010.

\section{Results in social, economic and environmental aspects}

\section{Social aspect}

The level of each of the three analysed indicators of social aspects is very different in each commune (Table 1). This means that each commune shows a large spread with regard to the indicators tested. In voter turnout, the figures range between 59\% in Puszczykowo and 38\% in Poznan. Generally, it should be noted that the electoral activity of agglomeration inhabitants is not high. A certain regularity is notable: in rural, smaller and less urbanised areas, participation in local elections is higher than in urban areas.

The share of people on social assistance benefits in the surveyed communes is low and relatively non-diversified. It varies from $1.8 \%$ in the commune of Komorniki to $6.8 \%$ in that of Kleszczewo. In general, this indicator is slightly better in communes directly adjacent to Poznań, an exception to this rule being the wealthy Tarnowo Podgórne, which takes one of the last places in the agglomeration in this respect. On the other hand, this indicator is above average for Poznań, although, as a large city, it is highly diversified socially. Such a situation is certainly associated with low levels of unemployment across the agglomeration. 
Table 1. Differences among the communes of the Poznan agglomeration in terms of social indicators.

\begin{tabular}{|c|c|c|c|c|c|c|c|c|c|c|c|}
\hline Commune & 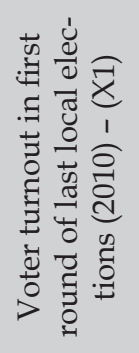 & 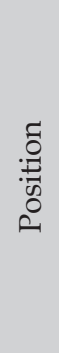 & 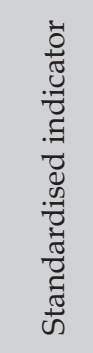 & 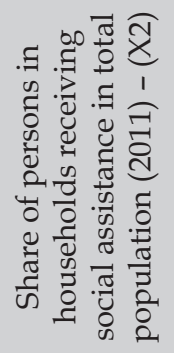 & $\begin{array}{l}\stackrel{f}{0} \\
: \stackrel{f}{D} \\
0 \\
0\end{array}$ & 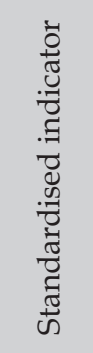 & 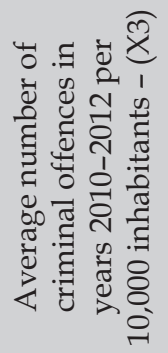 & 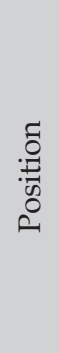 & 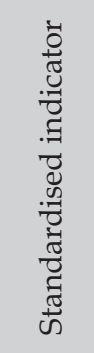 & 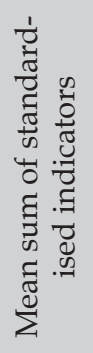 & $\begin{array}{l}0 \\
: 0 \\
: 0 \\
0 \\
0\end{array}$ \\
\hline Buk & 48.61 & 10 & 0.00 & 5.10 & 13 & -0.65 & 58.82 & 6 & 0.65 & 0.00 & 11 \\
\hline Czerwonak & 42.27 & 16 & -1.24 & 4.00 & 8 & 0.29 & 108.55 & 15 & -0.32 & -0.42 & 16 \\
\hline Dopiewo & 51.47 & 6 & 0.56 & 5.30 & 16 & -0.82 & 67.90 & 8 & 0.48 & 0.07 & 10 \\
\hline Kleszczewo & 55.07 & 2 & 1.27 & 6.80 & 18 & -2.10 & 72.58 & 9 & 0.38 & -0.15 & 13 \\
\hline Komorniki & 44.86 & 14 & -0.73 & 1.80 & 1 & 2.17 & 107.87 & 14 & -0.30 & 0.38 & 4 \\
\hline Kostrzyn & 39.81 & 17 & -1.72 & 4.80 & 12 & -0.39 & 35.38 & 2 & 1.11 & -0.34 & 14 \\
\hline Kórnik & 47.33 & 12 & -0.25 & 5.10 & 14 & -0.65 & 105.45 & 12 & -0.26 & -0.39 & 15 \\
\hline Luboń & 44.05 & 15 & -0.89 & 3.10 & 4 & 1.06 & 107.65 & 13 & -0.30 & -0.04 & 12 \\
\hline Mosina & 51.83 & 5 & 0.63 & 3.80 & 6 & 0.46 & 41.03 & 3 & 1.00 & 0.70 & 2 \\
\hline $\begin{array}{l}\text { Murowana } \\
\text { Goślina }\end{array}$ & 48.16 & 11 & -0.08 & 3.70 & 5 & 0.55 & 61.50 & 7 & 0.60 & 0.36 & 5 \\
\hline Pobiedziska & 52.50 & 3 & 0.76 & 4.70 & 11 & -0.31 & 104.35 & 11 & -0.23 & 0.07 & 9 \\
\hline Poznań & 38.43 & 18 & -1.99 & 3.89 & 7 & 0.38 & 223.88 & 18 & -2.56 & -1.39 & 18 \\
\hline Puszczykowo & 59.03 & 1 & 2.04 & 4.40 & 9 & -0.05 & 49.94 & 5 & 0.82 & 0.94 & 1 \\
\hline Rokietnica & 52.14 & 4 & 0.69 & 4.40 & 10 & -0.05 & 48.14 & 4 & 0.86 & 0.50 & 3 \\
\hline Stęszew & 49.65 & 9 & 0.21 & 5.60 & 17 & -1.08 & 32.42 & 1 & 1.17 & 0.10 & 8 \\
\hline Suchy Las & 51.10 & 7 & 0.49 & 2.50 & 2 & 1.57 & 156.69 & 16 & -1.25 & 0.27 & 6 \\
\hline Swarzędz & 47.33 & 13 & -0.25 & 3.10 & 3 & 1.06 & 93.89 & 10 & -0.03 & 0.26 & 7 \\
\hline $\begin{array}{l}\text { Tarnowo } \\
\text { Podgórne }\end{array}$ & 51.02 & 8 & 0.48 & 5.20 & 15 & -0.74 & 185.94 & 17 & -1.82 & -0.69 & 17 \\
\hline $\begin{array}{l}\text { arithmetic } \\
\text { mean }\end{array}$ & 48.59 & - & - & 4.34 & - & - & 92.33 & - & - & - & - \\
\hline $\begin{array}{l}\text { standard } \\
\text { deviation }\end{array}$ & 5.11 & - & - & 1.17 & - & - & 51.39 & - & - & - & - \\
\hline
\end{tabular}

Source: Local Data Bank of the Polish Central Statistical Office, National Electoral Commission, Police Headquarters in Poznań.

As an indicator of security, the average number of criminal offences in the years 2010-2012 was used. As expected, the highest offence level is observed in Poznań - 224 offences per 10,000 inhabitants, while the commune of Stęszew is the safest with its 32 offences per 10,000 inhabitants. One can also note a general regularity that higher offence rates are found in communes bordering Poznań and featuring a fast urbanisation rate.

As for the mean value of the three social indicators, Puszczykowo is the highest ranking commune, but in terms of the proportion of social assistance beneficiaries it is only in the ninth position. Significantly the lowest level of social indicators is found in Poznan, which stands out negatively against other communes in terms of voter turnout and the number of criminal offences. The position of the commune of Tarnowo Podgórne, which has been the agglomeration's most intensively developing commune in economic terms for the past 20 years, is surprisingly low.

\section{Economic aspect}

The indicators describing the economic determinants of the quality of life in the Poznan agglomeration differ quite widely in its individual communes (Table 2).

The per capita income in six out of the 18 communes is above the average for the agglomeration. The richest commune, Suchy Las, has a per capita budget nearly $80 \%$ higher than the average and more than 2.5 times higher than the communes with the lowest income: Lubon and Kostrzyn. Poznan, which is home to about $60 \%$ of the agglomeration's population, ranks third, with 
Table 2. Differences in the economic determinants of the quality of life in the communes of the Poznan agglomeration.

\begin{tabular}{|c|c|c|c|c|c|c|c|c|c|c|c|}
\hline Commune & 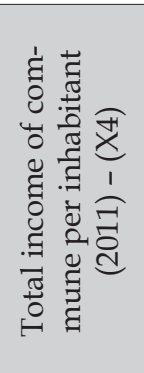 & 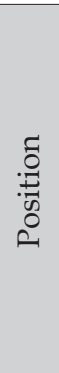 & 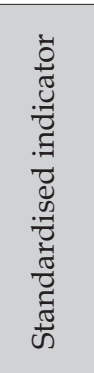 & 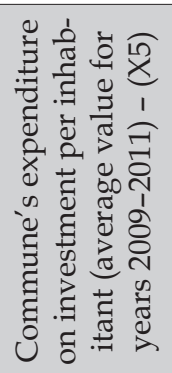 & 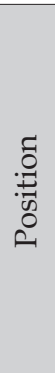 & 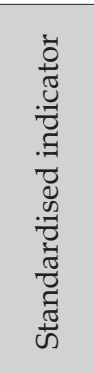 & 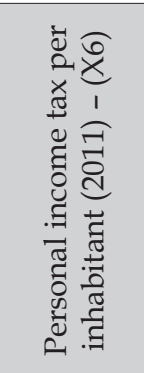 & 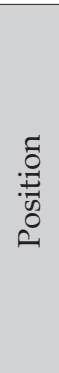 & 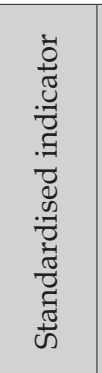 & 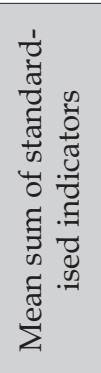 & 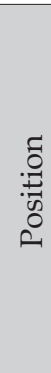 \\
\hline Buk & $3,338.42$ & 6 & 0.05 & 794.72 & 6 & -0.31 & 574.51 & 15 & -0.9 & -0.39 & 10 \\
\hline Czerwonak & $2,889.29$ & 11 & -0.39 & 430.15 & 11 & -0.97 & 766.11 & 9 & -0.23 & -0.53 & 12 \\
\hline \begin{tabular}{|l} 
Dopiewo \\
\end{tabular} & 3,026 & 8 & -0.25 & $1,192.37$ & 8 & 0.42 & 961.34 & 5 & 0.46 & 0.21 & 7 \\
\hline Kleszczewo & $3,091.61$ & 7 & -0.19 & $1,051.97$ & 7 & 0.16 & 724.58 & 10 & -0.37 & -0.13 & 9 \\
\hline Komorniki & $3,548.91$ & 5 & 0.25 & $1,386.5$ & 5 & 0.77 & 825.08 & 7 & -0.02 & 0.33 & 5 \\
\hline Kostrzyn & $2,179.26$ & 17 & -1.08 & 638.22 & 17 & -0.59 & 461.72 & 18 & -1.3 & -0.99 & 18 \\
\hline Kórnik & $3,952.76$ & 4 & 0.65 & $1,312.57$ & 4 & 0.64 & 800.35 & 8 & -0.11 & 0.39 & 4 \\
\hline Luboń & $2,136.65$ & 18 & -1.12 & 386.48 & 18 & -1.05 & 717.06 & 11 & -0.4 & -0.86 & 15 \\
\hline Mosina & $2,740.96$ & 13 & -0.53 & 631.06 & 13 & -0.61 & 642.07 & 13 & -0.66 & -0.60 & 13 \\
\hline $\begin{array}{l}\text { Murowana } \\
\text { Goślina }\end{array}$ & $2,643.37$ & 14 & -0.63 & 386.59 & 14 & -1.05 & 554.19 & 16 & -0.97 & -0.88 & 16 \\
\hline Pobiedziska & $2,871.57$ & 12 & -0.4 & 730.55 & 12 & -0.43 & 627.56 & 14 & -0.72 & -0.52 & 11 \\
\hline Poznań & $4,459.07$ & 3 & 1.14 & $1,543.68$ & 3 & 1.06 & $1,296.47$ & 3 & 1.64 & 1.28 & 3 \\
\hline Puszczykowo & $2,939.93$ & 10 & -0.34 & 630.81 & 10 & -0.61 & $1,314.86$ & 2 & 1.71 & 0.25 & 6 \\
\hline Rokietnica & $2,508.59$ & 15 & -0.76 & 429.64 & 15 & -0.98 & 679.12 & 12 & -0.53 & -0.76 & 14 \\
\hline Stęszew & $2,439.02$ & 16 & -0.82 & 613.28 & 16 & -0.64 & 490.4 & 17 & -1.2 & -0.89 & 17 \\
\hline Suchy Las & $5,987.63$ & 1 & 2.63 & $2,431.79$ & 7 & 2.68 & $1,288.31$ & 4 & 1.61 & 2.31 & 1 \\
\hline Swarzędz & $2,978.92$ & 9 & -0.3 & 917.62 & 9 & -0.08 & 900.84 & 6 & 0.25 & -0.04 & 8 \\
\hline \begin{tabular}{|l|} 
Tarnowo \\
Podgórne
\end{tabular} & $5,434.36$ & 2 & 2.09 & $1,840.96$ & 2 & 1.6 & $1,325.15$ & 1 & 1.74 & 1.81 & 2 \\
\hline \begin{tabular}{|l} 
arithmetic \\
mean
\end{tabular} & $3,287.02$ & - & - & 963.83 & - & - & 830.54 & - & - & - & - \\
\hline $\begin{array}{l}\text { standard } \\
\text { deviation }\end{array}$ & $1,028.29$ & - & - & 547.38 & - & - & 283.86 & - & - & - & - \\
\hline
\end{tabular}

Source: Local Data Bank of the Polish Central Statistical Office.

per capita income significantly lower than in the communes of Suchy Las and Tarnowo Podgórne. The analysed indicator varies much more widely among communes with above-average incomes than among those with a lower income. In the latter group, differences are slightly in excess of PLN 1,100 per capita, while in the more affluent communes this figure is PLN 2,700 per capita. The richer communes neighbour on Poznań and are located along one of the trunk roads, but, interestingly, the wealthiest communes have no motorway exit within their territory. It seems that they took advantage of their location before getting a motorway connection with Warsaw and Berlin.

To illustrate the investment activity of the communes, their expenditure on investment per inhabitant was used (mean value for the years 2009-2011). The position of communes in the ranking in terms of investment rate is very similar to the ranking by income rate, but the range of investment outlays in the agglomeration's communes is far greater than that of income. Investment-related spending per capita in the commune of Suchy Las is 2.5 times higher than the average for the agglomeration and more than six times higher than in the least investing communes - Luboń and Murowana Goślina. The level of investment in those communes is 2.5 times lower than the average in the agglomeration. The features of communes with above-average investment levels are similar to those related to income. Only the commune of Buk ranks considerably lower in terms of investment than income, 
which may result from its lower urbanisation level.

The third of the economic indicators reflects the wealth of the inhabitants. It has a distinctly different distribution than the other two economic parameters. The group of four communes with the highest level of income includes Puszczykowo, which ranks well below the average for the agglomeration in terms of funds at the disposal of the commune and capital expenditure. Lubon is a similar case - its inhabitants earn proportionally higher incomes than the local government. In general, differences in average per capita income are considerable: for Tarnowo Podgórne, the indicator is almost three times higher than for the inhabitants of Kostrzyn, where the indicator is almost half the average. Given the very high dynamics of migration of the agglomeration's inhabitants, especially in the past decade, it can be concluded that the position of communes in terms of their inhabitants' income reflects their attractiveness for living to people with higher incomes. In this sense, the preferred commune has traditionally been Tarnowo Podgórne, which borders Poznan in the west, due to good communication routes and good investment in housing. Puszczykowo, the garden town located in the vicinity of a national park, has been the location of choice for the wealthy Poznań residents for a century. Poznań ranks third in terms of personal wealth, which means that the centre of the agglomeration is still attractive to wealthy individuals as a place of residence. One has to bear in mind, however, that the share of the poorer sections of society in a large city is usually higher than in urbanising suburban communes. The group of the wealthiest communes also includes Suchy Las, which borders Poznań in the north. The attractiveness of the commune is partly due to the proximity of the centre and the lack of old and cumbersome industrial plants. Proportionally the lowest income is earned by the inhabitants of communes with a small town surrounded by agricultural land. They are located outside the immediate vicinity of Poznan, which means that suburbanisation processes are less intense here. The wealth rate in the communes of Kostrzyn and Stęszew is almost one-third of that in the wealthiest commune of Tarnowo Podgórne.
When considered collectively, the economic indicators of the quality of life show that the communes clearly standing out (with the highest average values) are Suchy Las and Tarnowo Podgórne. The top ranking of Suchy Las is mainly due to its by far highest rate of investment, which is one standard deviation higher than that for the second-ranking Tarnowo Podgórne. Poznań ranks third in all three economic sub-indicators and remains in the same position after their aggregation. The group with the lowest economic indicators includes urban and rural communes not bordering Poznan. This group also includes Lubon, which is the lowest-ranking commune bordering the metropolis. On the other hand, the town and commune of Buk is top-ranked among communes located on the periphery of the agglomeration.

\section{Environmental aspect}

The environmental indicators used for the purpose of this study are characterised by different levels of controllability and high variability throughout the agglomeration. The first shows investment activity of the communes in the area of environmental protection (the sewerage system), the second illustrates the relationship between the inherited structure of land development with the amount of attention paid to improving its density and expenditure on public transport in the communes, while the third relates to natural beauty.

The share of the population with access to the sewerage system is primarily a measure of comfort associated with eliminating the cumbersome transport of liquid waste. It can also be associated with the level of impact of sewerage from the commune on water quality. By far the highest level of accessibility to the sewerage system is observed in Poznan (90.8\%), while in four communes less than $40 \%$ of the population has access to one (Table 3). This indicator should be significantly improved in a few years since some communes currently invest heavily in sewerage, which will soon improve their ranking (e.g. Czerwonak, Murowana Goślina, Pobiedziska, Swarzędz).

The second environmental indicator shows the availability of public transport. Its ecology-friendly dimension is associated with a reduced need 
Table 3. Differences in the environmental determinants of the quality of life in the communes of the Poznan agglomeration.

\begin{tabular}{|c|c|c|c|c|c|c|c|c|c|c|c|}
\hline Commune & 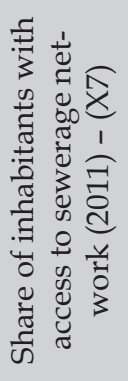 & 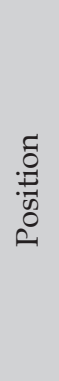 & 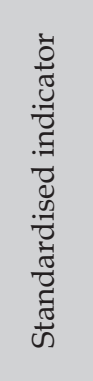 & 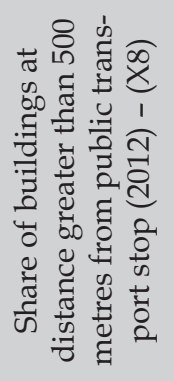 & 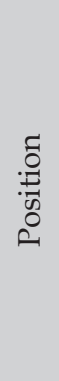 & 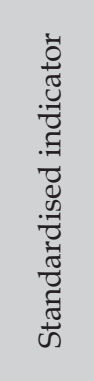 & 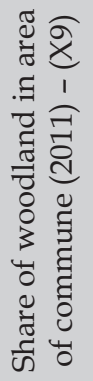 & 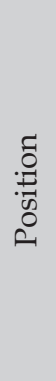 & 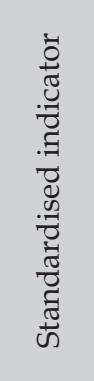 & 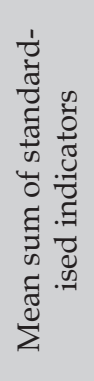 & $\begin{array}{l}\frac{5}{0} \\
. \\
0 \\
0 \\
0\end{array}$ \\
\hline Buk & 34.00 & 17 & -1.45 & 25.78 & 15 & -1.36 & 3.71 & 17 & -1.15 & -1.32 & 18 \\
\hline Czerwonak & 68.70 & 3 & 0.82 & 61.65 & 8 & 0.28 & 39.91 & 3 & 1.34 & 0.81 & 2 \\
\hline Dopiewo & 53.40 & 12 & -0.18 & 54.92 & 10 & -0.03 & 15.54 & 10 & -0.33 & -0.18 & 12 \\
\hline Kleszczewo & 37.50 & 15 & -1.22 & 78.99 & 4 & 1.07 & 2.23 & 18 & -1.25 & -0.47 & 13 \\
\hline Komorniki & 58.20 & 8 & 0.13 & 24.78 & 17 & -1.40 & 15.92 & 9 & -0.31 & -0.53 & 16 \\
\hline Kostrzyn & 66.50 & 4 & 0.67 & 46.11 & 13 & -0.43 & 13.24 & 12 & -0.49 & -0.08 & 10 \\
\hline Kórnik & 33.40 & 18 & -1.49 & 45.55 & 14 & -0.45 & 26.45 & 6 & 0.41 & -0.51 & 14 \\
\hline Luboń & 66.40 & 5 & 0.66 & 88.26 & 1 & 1.50 & 3.73 & 16 & -1.14 & 0.34 & 6 \\
\hline Mosina & 57.00 & 10 & 0.05 & 48.93 & 12 & -0.30 & 37.18 & 4 & 1.15 & 0.30 & 8 \\
\hline $\begin{array}{l}\text { Murowana } \\
\text { Goślina }\end{array}$ & 49.80 & 13 & -0.42 & 50.17 & 11 & -0.24 & 45.39 & 2 & 1.72 & 0.35 & 5 \\
\hline Pobiedziska & 40.50 & 14 & -1.03 & 16.44 & 18 & -1.78 & 24.36 & 7 & 0.27 & -0.85 & 17 \\
\hline Poznań & 90.80 & 1 & 2.26 & 83.28 & 2 & 1.27 & 14.15 & 11 & -0.43 & 1.03 & 1 \\
\hline Puszczykowo & 35.20 & 16 & -1.37 & 59.06 & 9 & 0.16 & 51.16 & 1 & 2.11 & 0.30 & 7 \\
\hline Rokietnica & 58.10 & 9 & 0.12 & 65.66 & 6 & 0.46 & 7.59 & 14 & -0.88 & -0.10 & 11 \\
\hline Stęszew & 56.20 & 11 & 0.00 & 24.90 & 16 & -1.40 & 17.77 & 8 & -0.18 & -0.53 & 15 \\
\hline Suchy Las & 65.10 & 7 & 0.58 & 72.66 & 5 & 0.78 & 29.78 & 5 & 0.64 & 0.67 & 3 \\
\hline Swarzędz & 75.40 & 2 & 1.25 & 83.04 & 3 & 1.26 & 12.85 & 13 & -0.52 & 0.66 & 4 \\
\hline $\begin{array}{l}\text { Tarnowo } \\
\text { Podgórne }\end{array}$ & 65.90 & 6 & 0.63 & 62.30 & 7 & 0.31 & 6.33 & 15 & -0.97 & -0.01 & 9 \\
\hline arithmetic mean & 56.23 & - & - & 55.14 & - & - & 20.41 & - & - & - & - \\
\hline $\begin{array}{l}\text { standard } \\
\text { deviation }\end{array}$ & 15.30 & - & - & 21.34 & - & - & 14.57 & - & - & - & - \\
\hline
\end{tabular}

Source: Local Data Bank of the Polish Central Statistical Office, Study of the Spatial Planning of the Poznań Agglomeration.

for the use of a private car and, consequently, reduced exhaust emission and consumption of fossil fuels. It facilitates the mobility of people who do not use private cars. The greatest availability of public transport is found in the commune of Lubon as well as Poznań and Swarzędz, where more than $80 \%$ of housing is located within 500 metres from a stop. At the other extreme is the commune of Pobiedziska, where the indicator is $16 \%$. It is also very low in three other communes, approximately $25 \%$. The average for the entire agglomeration exceeds $55 \%$, which should be considered a good level of transport accessibility. It is necessary to note, however, that an additional availability factor is the frequency of public transport, which is not included at this level of research generality (cf. Lechniak, Mizgajski 2008).
The Poznań agglomeration has a significant share of areas of outstanding natural beauty. In the course of preparing the Study of the Spatial Planning of the Poznan Agglomeration, the spatial distribution of a three-tier green network consisting of areas with significant natural and recreational features was developed for the agglomeration (Mizgajski, Zwierzchowska 2011). However, the use of those data for the construction of the indicator would impede broader comparative analyses due to its highly detailed nature. A very high correlation between the share of natural environment preservation areas and the share of woodland in the communes $(0.88)$ shows that the proportion of forests in the territory of a commune accurately reflects its attractiveness for recreational purposes. The average 
share of woodland in the whole agglomeration is approximately $20 \%$, and varies from $51 \%$ in Puszczykowo to less than $4 \%$ in the communes of Buk and Luboń and 2\% in Kleszczewo.

When comparing the environmental indicators for individual communes, it can be noted that the top-ranking communes show the most significant differences in position in terms of individual parameters, which means that there is not a single commune that would have high values of all environmental parameters. Poznan ranks at the top, although in terms of the share of attractive areas for recreation it is at the average level for the whole of the agglomeration. The weaker side of the commune of Czerwonak, which is ranked second, is the average availability of public transport. The average level of environmental indicators puts the commune of Suchy Las in the third place, but in terms of specific aspects it ranks only slightly higher than the average for the entire agglomeration.

\section{Classification of communes in terms of living conditions}

The synthetic indicator of determinants of the quality of life for the inhabitants of the various communes was calculated as the average of all nine parameters. The classification of the communes by this indicator made it possible to divide them into five classes (Table 4).

To analyse the differences and similarities among communes in terms of the level of the various analytical indicators, a radial diagram was used (Figs 1-5).

The class with the highest level of the synthetic indicator includes only one commune, Suchy Las. It has by far the highest economic indicators, especially income and investment outlays. Suchy Las stands out positively in terms of the affluence of its inhabitants and a low proportion of social assistance beneficiaries. The offence rate is significantly below the average for the agglomeration.

The group with favourable determinants is formed by four communes clearly differentiated in terms of their strengths and weaknesses.

Table 4. Classification of the agglomeration's communes by the synthetic indicator of determinants of the quality of life.

\begin{tabular}{|c|c|c|c|c|c|c|c|c|c|c|c|c|}
\hline \multirow[t]{2}{*}{ Commune } & \multicolumn{3}{|c|}{$\begin{array}{c}\text { Social } \\
\text { indicators }\end{array}$} & \multicolumn{3}{|c|}{$\begin{array}{l}\text { Economic } \\
\text { indicators }\end{array}$} & \multicolumn{3}{|c|}{$\begin{array}{l}\text { Environmental } \\
\text { indicators }\end{array}$} & \multirow{2}{*}{$\begin{array}{l}\text { Mean sum } \\
\text { of } X 1-X 9\end{array}$} & \multirow[t]{2}{*}{ Position } & \multirow[t]{2}{*}{ Class } \\
\hline & $\mathrm{X} 1$ & $\mathrm{X} 2$ & X3 & $\mathrm{X} 4$ & X5 & X6 & $\mathrm{X} 7$ & $\mathrm{X} 8$ & X9 & & & \\
\hline Suchy Las & 0.49 & 1.57 & -1.25 & 2.63 & 2.68 & 1.61 & 0.58 & 0.78 & 0.64 & 1.08 & 1 & I \\
\hline Puszczykowo & 2.04 & -0.05 & 0.82 & -0.34 & -0.61 & 1.71 & -1.37 & 0.16 & 2.11 & 0.50 & 2 & II \\
\hline $\begin{array}{l}\text { Tarnowo } \\
\text { Podgórne }\end{array}$ & 0.48 & -0.74 & -1.82 & 2.09 & 1.60 & 1.74 & 0.63 & 0.31 & -0.97 & 0.37 & 3 & II \\
\hline Poznań & -1.99 & 0.38 & -2.56 & 1.14 & 1.06 & 1.64 & 2.26 & 1.27 & -0.43 & 0.31 & 4 & II \\
\hline Swarzędz & -0.25 & 1.06 & -0.03 & -0.30 & -0.08 & 0.25 & 1.25 & 1.26 & -0.52 & 0.29 & 5 & II \\
\hline Mosina & 0.63 & 0.46 & 1.00 & -0.53 & -0.61 & -0.66 & 0.05 & -0.30 & 1.15 & 0.13 & 6 & III \\
\hline Komorniki & -0.73 & 2.17 & -0.30 & 0.25 & 0.77 & -0.02 & 0.13 & -1.40 & -0.31 & 0.06 & 7 & III \\
\hline Dopiewo & 0.56 & -0.82 & 0.48 & -0.25 & 0.42 & 0.46 & -0.18 & -0.03 & -0.33 & 0.03 & 8 & III \\
\hline Czerwonak & -1.24 & 0.29 & -0.32 & -0.39 & -0.97 & -0.23 & 0.82 & 0.28 & 1.34 & -0.05 & 9 & III \\
\hline $\begin{array}{l}\text { Murowana } \\
\text { Goślina }\end{array}$ & -0.08 & 0.55 & 0.60 & -0.63 & -1.05 & -0.97 & -0.42 & -0.24 & 1.72 & -0.06 & 10 & III \\
\hline Rokietnica & 0.69 & -0.05 & 0.86 & -0.76 & -0.98 & -0.53 & 0.12 & 0.46 & -0.88 & -0.12 & 11 & IV \\
\hline Kórnik & -0.25 & -0.65 & -0.26 & 0.65 & 0.64 & -0.11 & -1.49 & -0.45 & 0.41 & -0.17 & 12 & IV \\
\hline Luboń & -0.89 & 1.06 & -0.30 & -1.12 & -1.05 & -0.40 & 0.66 & 1.50 & -1.14 & -0.19 & 13 & IV \\
\hline Kleszczewo & 1.27 & -2.10 & 0.38 & -0.19 & 0.16 & -0.37 & -1.22 & 1.07 & -1.25 & -0.25 & 14 & IV \\
\hline Pobiedziska & 0.76 & -0.31 & -0.23 & -0.40 & -0.43 & -0.72 & -1.03 & -1.78 & 0.27 & -0.43 & 15 & $\mathrm{~V}$ \\
\hline Stęszew & 0.21 & -1.08 & 1.17 & -0.82 & -0.64 & -1.20 & 0.00 & -1.40 & -0.18 & -0.44 & 16 & $\mathrm{~V}$ \\
\hline Kostrzyn & -1.72 & -0.39 & 1.11 & -1.08 & -0.59 & -1.30 & 0.67 & -0.43 & -0.49 & -0.47 & 17 & $\mathrm{~V}$ \\
\hline Buk & 0.00 & -0.65 & 0.65 & 0.05 & -0.31 & -0.90 & -1.45 & -1.36 & -1.15 & -0.57 & 18 & $\mathrm{~V}$ \\
\hline
\end{tabular}

Source: own calculations. 


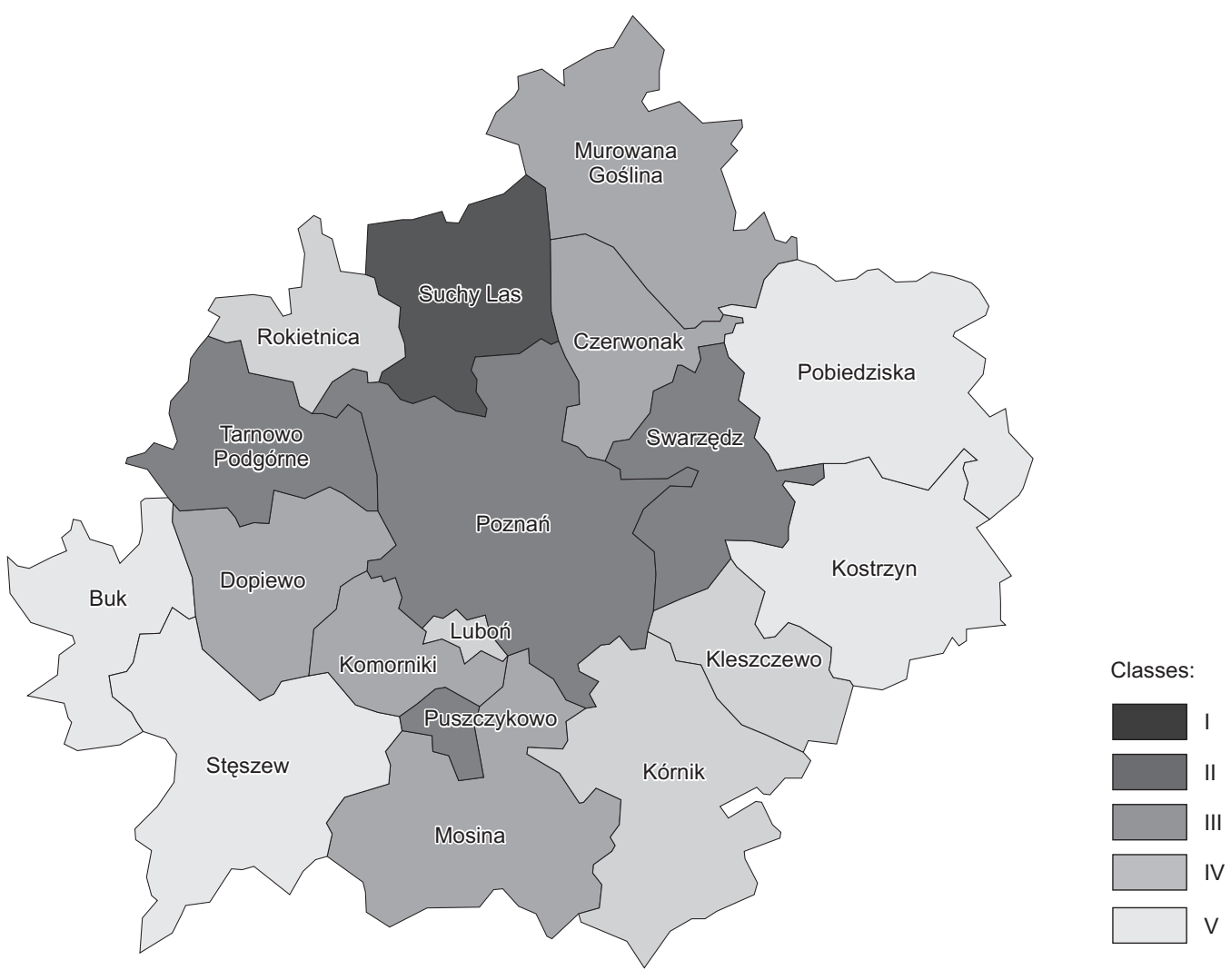

Map 1. Classification of communes in terms of the synthetic indicator of determinants of the quality of life.

Puszczykowo has one distinguishing feature in each of the analysed areas. The town is characterised by high wealth of its inhabitants, high voter turnout, and high availability of attractive sites for recreation. Other indicators are at an average or lower level. Tarnowo Podgórne and Poznań are characterised by a high level of all economic indicators. Another advantage of Poznan is a high level of environmental indicators, such as the sewerage system and the availability of public transport. However, the social indicators in Poznan are at the lowest level in the entire agglomeration. The position of Tarnowo Podgórne in this regard is also low. Swarzędz can be considered the commune with the best balance between the economic, environmental, and social aspects, as all its indicators oscillate around the mean figures for the agglomeration.

The class of territorial units with average living conditions (at the agglomeration scale) includes five communes (Fig. 3). Among them, Mosina and Murowana Goślina have a very similar distribution of figures, and are characterised by above-average values of social indicators and a high proportion of attractive natural sites. The economic indicators in the two communes are below average. In this group, only Komorniki has above-average economic indicators. The remain-

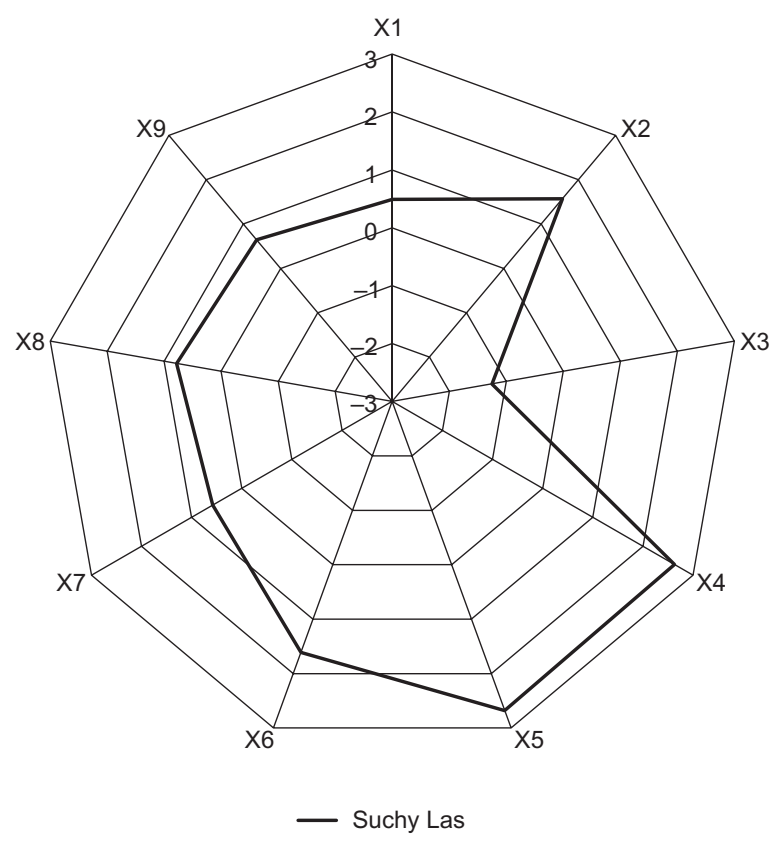

Fig. 1. Distribution of the values of normalised indicators in the commune of Suchy Las, which has the best determinants of the quality of life in the Poznan agglomeration. Source: own material. 


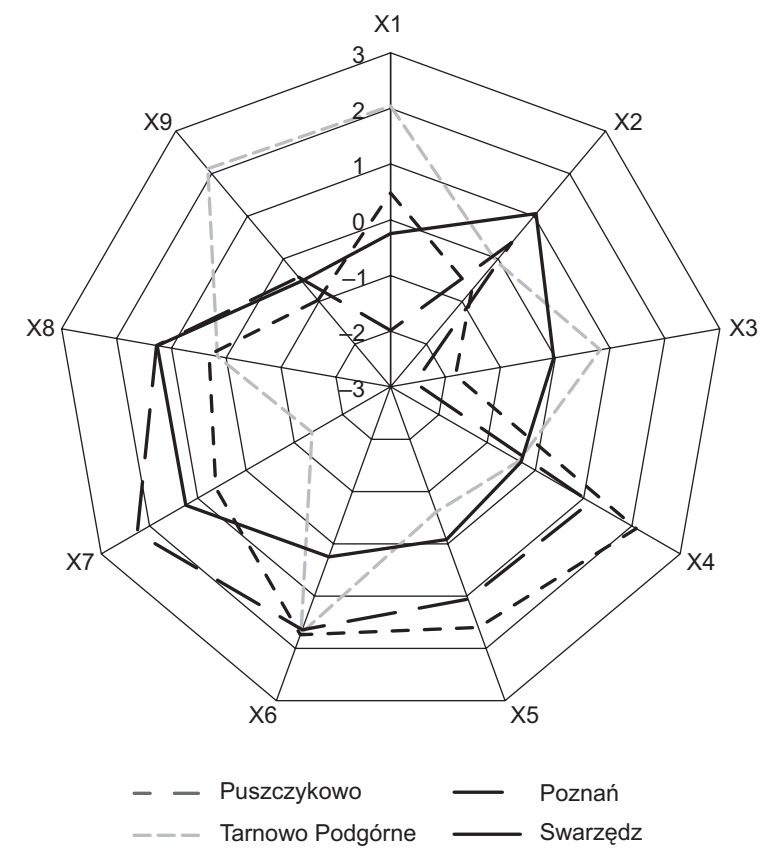

Fig. 2. Distribution of the values of normalised indicators in communes with favourable determinants of the quality of life as compared with the Poznań agglomeration. Source: own material.

ing indicators in this commune differ widely. It has the lowest proportion of people on social assistance benefits, and at the same time the lowest access to public transport. Dopiewo is characterised by high capital investment considering

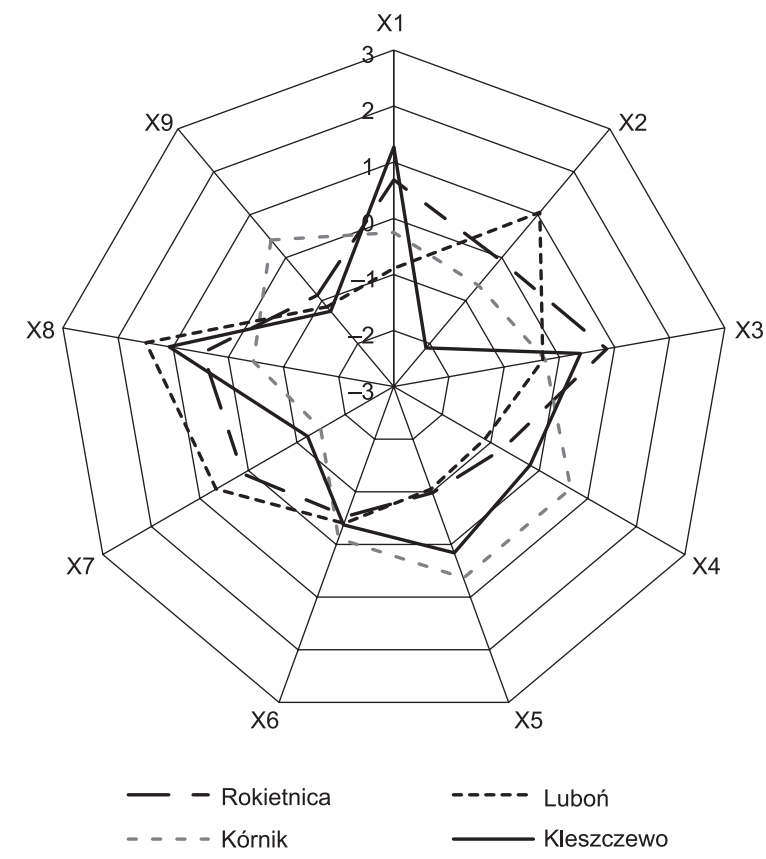

Fig. 4. Distribution of the values of normalised indicators in communes with relatively less favourable determinants of the quality of life as compared with the Poznań agglomeration.

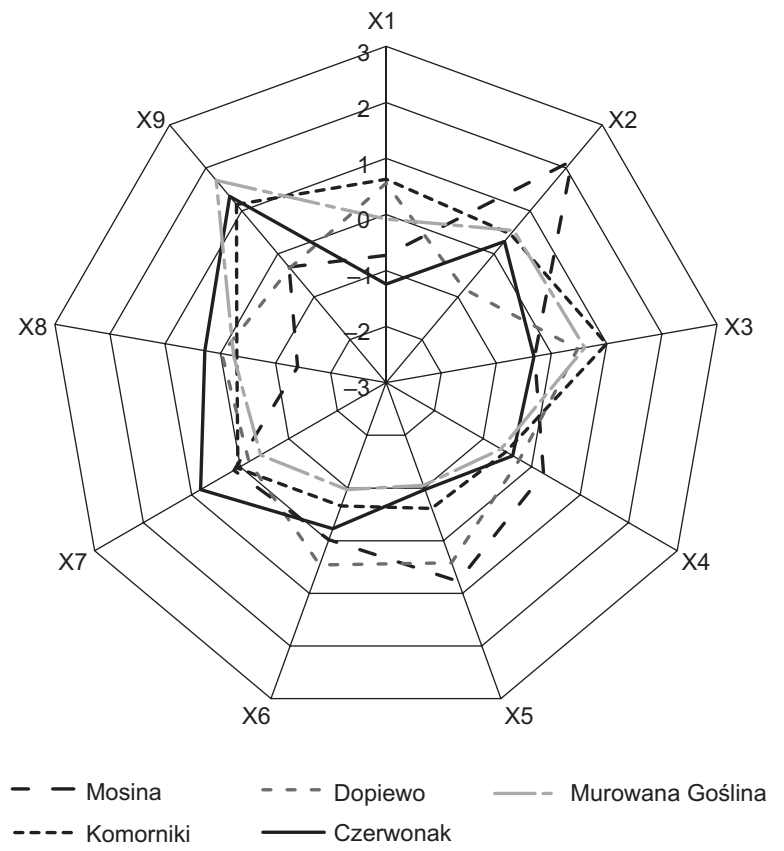

Fig. 3. Distribution of the values of normalised indicators in communes with average determinants of the quality of life as compared with the Poznań agglomeration. Source: own material.

its lower-than-average income. In the group, it has the highest (above-average) tax revenues. The remaining indicators are at an average level, except for the largest share of persons on social assistance benefits in this group. The position of

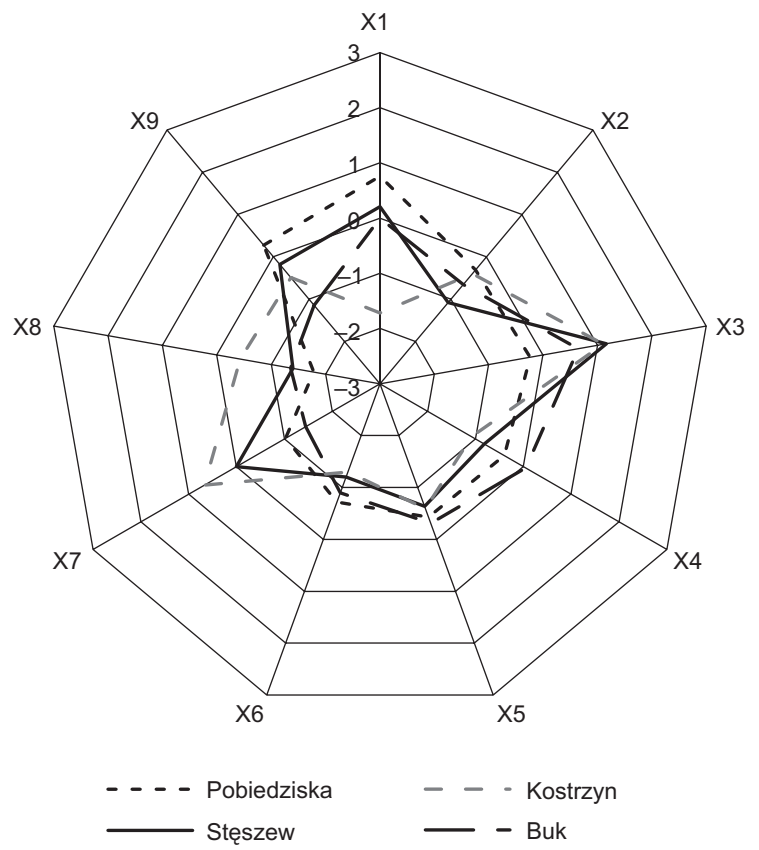

Fig. 5. Distribution of the values of normalised indicators in communes with relatively unfavourable determinants of the quality of life as compared with the Poznan agglomeration. Source: own material. 
the commune of Czerwonak was affected by its above-average environmental indicators and a small percentage of social assistance beneficiaries. The remaining indicators are lower than average for the agglomeration.

The group with the determinants of the quality of life below the average for the agglomeration includes four communes (Fig. 4). Their common feature is, primarily, the lower-than-average wealth index as measured by the amount of personal income tax. They all have an average level of offences, while other indicators are more varied. Kórnik is the only commune where economic indicators are above average, but it also has the lowest access to public transport in the group and lower-than-average social indicators. Rokietnica has higher-than-average social indicators, but all economic indicators are below the average. Lubon, with the lowest economic indicators in the group, stands out positively in terms of access to the sewerage system and public transport. Kleszczewo is distinguished by an extremely high proportion of the poor, while in Lubon this rate is more favourable than the average for the agglomeration.

A common feature of all four communes in the group with the least favourable determinants of the quality of life is significantly lower-than-average economic parameters (Fig. 5). This fact is certainly associated with lower-than-average availability of public transport and negative social assistance indicators. An interesting feature of this group is the above-average participation in elections and the lower-than-average offence rate (except for Pobiedziska). Also, there are significant differences in the environmental parameters.

\section{Conclusions}

According to the authors, the set of indicators used in the analysis can greatly reflect significant factors affecting the quality of life of the communes' inhabitants. The parameters employed relate to a commune as a whole, so the results do not allow an analysis of differences within each unit. The design of the synthetic indicator and the classification of the communes based thereon are the authors' own proposal, which is relatively simple and easy to understand while giving interesting cognitive results and reflecting fundamental differences in living conditions across the agglomeration.

It should be emphasised that the comparative study of the communes of the Poznan agglomeration concerned the relative position of the various communes in an urban area with the highest standard of living in Poland. This means that the results obtained are not eligible for the purposes of making any absolute judgements, and they only indicate the ranking of the agglomeration's communes relative to one other. It should also be pointed out that some of the indicators reflect external factors on which the communes have no influence.

Quality-of-life surveys are one way to monitor socio-economic development and verify the performance and efficiency of local governments' work. They also assess whether the aims and objectives pursued by public authorities translate into results in the form of improved living conditions of the inhabitants. In this respect, what matters is not only the results of studying the subjective feelings of inhabitants, but also test methods that use hard and objectified indicators.

The quality of life is a strategic objective, frequently emphasised in the development strategies of cities and communes. It is no different in the Poznan agglomeration. Despite the fact that quality-of-life issues receive significant attention from the media and, no doubt, from the inhabitants themselves, local authorities still make little use of quality-of-life surveys as a tool for planning and monitoring socio-economic development. In this respect, Poznań can be regarded as a national leader and forerunner of research on the quality of life. The research and analyses developed for Poznań are very detailed ones. To date, the weakness of Poznan-related research on the quality of life has been the lack of positioning Poznan against the fast-growing neighbouring communes, which, not accidentally, attract an increasing number of its inhabitants and businesses.

The development of urbanisation processes raises the standard of living also in suburban areas where, in the recent years, at least two communes (Suchy Las and Tarnowo Podgórne) have been offering better living conditions that 
the central city of Poznan. In connection with the outflow of inhabitants from the central city to the suburbs and its shrinking tax base, the city authorities have made efforts to inhibit this process. "Poznań as a metropolitan city with a strong economy, a high quality of life, and knowledge-based development" is the vision of Poznan formulated in the 2030 Development Strategy for the City of Poznań. Achieving this vision will be possible through the implementation of the strategic objective "Improving the quality of life and the attractiveness of the city's space and architecture", which covers a very wide range of functional and spatial issues, starting from the quality of living, through public transport and environmental quality, to building social capital among the inhabitants.

\section{References}

Berrini M., Bono L., 2010. Measuring urban sustainability. Analysis of the European Green Capital Award 2010 \& 2011 application round, Ambiente Italia.

Blomquist G.C., Berger M.C., Hoehn J.P., 1988. New estimates of quality of life in urban areas. The American Economic Review 78(1): 89-107.

Czapiński J., Panek T. (eds), 2011. Diagnoza społeczna 2011 - warunki i jakość życia Polaków (Social diagnosis 2011: Living conditions and the quality of life of Poles). Rada Monitoringu Społecznego, Warsaw.

EEA, 2009. Ensuring quality of life in Europe's cities and towns: Tackling the environmental challenges of European and global change. EEA Report No 5/2009. EEA, Copenhagen.

Gadziński J., 2012. Rozmieszczenie przystanków transportu publicznego (Distribution of public transport stops). In: Kaczmarek T. (ed.), Studium uwarunkowań rozwoju przestrzennego aglomeracji poznańskiej. Centrum Badań Metropolitalnych UAM, Poznań: 120-121.

Hamilton F.E. Ian, Andrews Dimitrovska K., Pichler-Milanovič N., 2005. Transformation of cities in Central and Eastern Europe: Towards globalisation. United Nations University Press, Tokyo, New York, Paris.

Kaczmarek T., 2012. Trendy i wyzwania rozwojowe (Development trends and challenges). In: Kaczmarek T. (ed.), Studium uwarunkowań rozwoju przestrzennego aglomeracji poznańskiej. Centrum Badań Metropolitalnych UAM, Poznań: 20-21.

Kaczmarek T., Mizgajski A. (eds), 2008. Powiat poznański. Jakość przestrzeni i jakość życia (Poznań poviat. The quality of space and the quality of life). Bogucki Wydawnictwo Naukowe, Poznań.

Lechniak M., Mizgajski A., 2008. Powiązania infrastrukturalne między Poznaniem a otaczającymi gminami (Infrastructural links between Poznań and its surrounding communes). In: Kaczmarek T., Mizgajski A. (eds), Powiat poznański. Jakość przestrzeni i jakość życia. Bogucki Wydawnictwo Naukowe, Poznań: 241-258.

Mizgajski A., Zwierzchowska I., 2012. Środowisko przyrodnicze (Natural environment). In: Kaczmarek T., (ed.), Studium uwarunkowań rozwoju przestrzennego aglomeracji poznańskiej. Centrum Badań Metropolitalnych UAM, Poznań: 48-61.

Strategia rozwoju aglomeracji poznańskiej - Metropolia Poznań 2020 (Poznań Agglomeration Development Strategy Poznań Metropolis 2020). Centrum Badań Metropolitalnych UAM, Poznań.

Tarzia V., 2003. European common indicators. Towards a local sustainability profile. Final Project Report Development, Refinement, Management and Evaluation of European Common Indicators Project (ECI). Ambiente Italia Research Institute, Milano, Italy.

Tasan T., 1999. Warsaw under transformation: New tendencies in the housing market. GeoJournal 49: 91-103.

Walaszek M., 2012. Jakość życia w Poznaniu - porównanie krajowe (Quality of life in Poznań: A country-wide comparison). In: Kaczmarek T. (ed.), Pozycja konkurencyjna Poznania wśród metropolii krajowych i europejskich. Biblioteka Aglomeracji Poznańskiej No. 22, Bogucki Wydawnictwo Naukowe, Poznań. 